Laboratoire de Recherche en Gestion $\&$ Economie

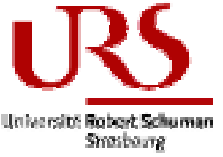

\section{AR $\cos 8 \mathrm{E}$}

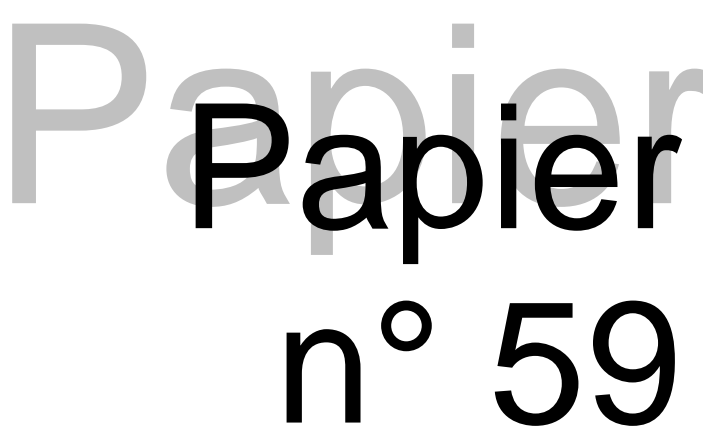

Can Mergers in Europe Help Banks Hedge Against Macroeconomic Risk

\section{Pierre-Guillaume Méon / Laurent Weill}

Faculté des

Septembre 2003

sciences économiques

et de gestion 


\title{
Can Mergers in Europe Help Banks Hedge Against Macroeconomic Risk?
}

\author{
Pierre-Guillaume Méon \\ Laurent Weill \\ Assistant Professor of Economics \\ Assistant Professor of Economics \\ (Corresponding author)
}

\begin{abstract}
LARGE,
Institut d'Etudes Politiques, Université Robert Schuman, 47 avenue de la Forêt-Noire, 67082 Strasbourg Cedex, France.

Phone: 33388417721 ; Fax: 33388417778

E-mail : laurent.weill@urs.u-strasbg.fr
\end{abstract}

Keywords: bank mergers, risk diversification, European integration.

JEL Classification: F15, G11, G21, G34.

Abstract

This paper investigates the motive of geographic risk diversification in the loan activity for bank mergers in the EU on a sample of large banking groups. Geographic diversification should allow banks to reduce their risk. We observe that the loan portfolios of European banks are home-biased. We apply the portfolio approach to explore the risk-return efficiency of the locations of banks' activities. We also study mergers between pairs of banks. We provide evidence on the sub-optimality of the loan portfolios of European banks in terms of geographic risk diversification and on the existence of potential gains from inter-country pair mergers. 


\section{Can Mergers in Europe Help Banks Hedge Against Macroeconomic Risk?}

\section{Introduction}

Since the beginning of the 1990s, an increasing wave of mergers is observable in European banking. A prime aim of research on bank mergers has therefore been to identify motives for bank mergers in the European Union. These motives, such as economies of scale or scope (Altunbas and Molyneux, 1996) and managerial efficiency (Vander Vennet, 1996), have already been studied in European bank mergers. The risk diversification motive, which can be summarized by the adage "don't put all your eggs in one basket”, has however been given less attention. This may in fact justify two different strategies: on the one hand, the diversification of activities between sectors of activity, for instance by creating a financial conglomerate including banking and insurance activities; on the other hand, geographic diversification. This strategy is based upon the fact that a company that operates in several countries can substantially limit its exposure to economic shocks and thereby reduce the risk associated with its activity.

The case of geographic diversification is especially relevant in banking, as bank performance is directly connected with economic activity. This relationship has been empirically illustrated in the literature. Clark and Wheelock (1997) for instance find that U.S. banks' earnings are strongly influenced by the economic growth of the states where they are located. Huh and Kim (1994) moreover observe that the bad loan rate is anticyclical in Japan and Korea. This also makes sense on a practical ground, as the $5^{\text {th }} \mathrm{C}$ of the $5 \mathrm{Cs}$ of creditworthiness used by bank credit analysts is "conditions", defined as economic conditions that affect the borrower's ability to repay the loan.

Consequently, as a bank's lending environment is heavily influenced by economic activity within the bank's operating environment, there is scope for risk reduction through geographic diversification of lending activities. Indeed, as Berger (2000) points out, banks may diversify risks because the returns of loans issued in different countries may have relatively low covariation. This is precisely this aspect of bank mergers that we investigate in 
this paper. Indeed our aim here is to evaluate the importance of the motive of geographic diversification of risk in the loan activity for European bank mergers.

The basic idea of our methodology is based on a representation of banks' lending environment that is obtained by forming country portfolios for European banking organizations based on the extent of their presence in different states. In the spirit of Gunther and Robinson (1999), we therefore use the portfolio approach to evaluate the relevance of the geographic diversification motive in European bank mergers.

These authors analyze the risk of US banks' loan portfolios by considering the mix of economic activities of the states in which they operate. They resort to the analogy between financial assets and industries in a portfolio analysis where the growth rate of an industry and the variance of its growth rate are the analogues to expected return and risk in financial portfolios. Each state is then considered as a collection of industries, and banks consequently build up industry portfolios by operating in different states. A bank's risk diversification is subsequently measured by the coefficient of variation of its industry portfolio. Gunther and Robinson demonstrate that this measure of risk diversification is positively correlated with the probability of bank failure, proving thereby the relevance of their approach.

However our methodology differs from Gunther and Robinson's in two important respects. Firstly, unlike these authors, we directly consider that countries are the basic assets of a bank’s loan portfolio. By operating in a country, a banking group takes a participation in an asset that is described by its growth rate and the variance of its growth rate. This specification seems more appealing because in the first place it is simpler. Indeed as the evolution of a GDP results from the addition of the evolution of all industries in a country, measuring diversification directly at the country level avoids unnecessary computations.

More to the point, as Gunther and Robinson compute industry performance at the federal level, they blur the effects of regional economic policies. Contrarywise, our methodology allows us to take into account the differences in national policies across EU members. The same method can be found in Goldberg and Levi (2000), who apply the portfolio approach to a set of countries considered as financial assets. However their aim is radically different, as they explore the potential diversification benefits of the European Union.

Secondly, we measure risk diversification by estimating a risk-return efficiency frontier, allowing to compare the effective risk to the optimal risk for a given level of return. This approach has two advantages over the coefficient of variation used by Gunther and Robinson. On one hand, it provides a benchmark measure. On the other hand, it takes into 
consideration the concavity of the risk-return efficiency frontier. Indeed, the drawback of Gunther and Robinson's risk diversification measure is that it does not allow to discriminate between a portfolio that is located on the efficient frontier and another portfolio with half as much risk and return, although the latter is unambiguously farther from the frontier than the former hence less efficient.

In this aim, we use macroeconomic data for all EU countries for the period 1960-1995 and accounting data for the 52 biggest European banking groups and their subsidiaries. This application of the portfolio approach to European banking raises four fundamental questions.

Q1: Could European banks have diversified their macroeconomic risk?

More precisely, we aim to know if business cycles are correlated across European countries. Indeed a perfect correlation between countries would result in the absence of opportunities for risk diversification. We then observe that such opportunities exist.

Q2: Have European banks diversified their macroeconomic risk?

Provided diversification opportunities exist, the point is to know whether European banks have taken advantage of these opportunities during our period of study. We observe that loan portfolios are clearly home-biased and conclude that European banks did not exploit these opportunities. However this observation does not mean that banks made inefficient decisions about the location of their activities in terms of risk-return management.

Q3: Were European banks risk-return efficient?

Using the portfolio approach, we show that the actual locations of the activities of European banks were not optimal, insofar as those groups could have benefited from a lower risk for the same expected return of their loan portfolio. Finally, as diversification is typically envisaged through mergers of pairs of banks, we come to the following question.

Q4: Could have mergers improved banks' risk-return efficiency?

We show that in general inter-country pairwise mergers of banks would have improved the risk-return efficiency of the banks involved.

The paper is organized so as to answer each question in turn. Namely, section 2 answers questions Q1 and Q2, while sections 3 and 4 respectively address questions Q3 and Q4. Section 5 concludes. 


\section{Could European banks have diversified their macroeconomic risk? Have they?}

In this section, we describe the data used in this study. In so doing, we ascertain that business cycles are not perfectly correlated across Europe and that there therefore exist opportunities for risk diversification. We subsequently observe a striking home bias in the activities of banking groups.

\subsection{Correlation analysis of business cycles}

To study the co-movements of business cycles across countries we compute the correlation of annual real GDP growth rates across the fifteen member countries of the European Union. Our data stem from the OECD Economic Outlook database. They cover the 1960-1995 period.

More specifically, we compute the contemporaneous correlation of GDP growth for each pair of countries. If business cycles are perfectly correlated between two countries, the coefficient of correlation of their GDP growth rates is equal to one and there does not exist any possibility of diversification. Therefore, the lower the coefficient of correlation, the greater the opportunities of diversification will be. Table 1 below displays our results.

Table 1: Coefficients of correlation between growth rates

\begin{tabular}{|c|c|c|c|c|c|c|c|c|c|c|c|c|c|c|}
\hline & AT & BE & DE & DK & ES & FI & FR & GB & GR & IE & IT & LU & NL & PT \\
\hline AT & 1.000 & & & & & & & & & & & & & \\
\hline BE & 0.708 & 1.000 & & & & & & & & & & & & \\
\hline DE & 0.672 & 0.739 & 1.000 & & & & & & & & & & & \\
\hline DK & 0.444 & 0.523 & 0.674 & 1.000 & & & & & & & & & & \\
\hline ES & 0.592 & 0.727 & 0.572 & 0.417 & 1.000 & & & & & & & & & \\
\hline FI & 0.418 & 0.529 & 0.415 & 0.361 & 0.470 & 1.000 & & & & & & & & \\
\hline FR & 0.747 & 0.865 & 0.754 & 0.579 & 0.815 & 0.538 & 1.000 & & & & & & & \\
\hline GB & 0.236 & 0.318 & 0.416 & 0.486 & 0.320 & 0.473 & 0.413 & 1.000 & & & & & & \\
\hline GR & 0.517 & 0.562 & 0.619 & 0.511 & 0.572 & 0.428 & 0.654 & 0.400 & 1.000 & & & & & \\
\hline IE & -0.056 & 0.027 & -0.007 & -0.088 & 0.036 & 0.113 & 0.000 & 0.088 & 0.047 & 1.000 & & & & \\
\hline IT & 0.595 & 0.748 & 0.579 & 0.425 & 0.708 & 0.452 & 0.783 & 0.321 & 0.478 & -0.016 & 1.000 & & & \\
\hline LU & 0.275 & 0.363 & 0.432 & 0.298 & 0.219 & 0.193 & 0.240 & 0.413 & 0.107 & 0.041 & 0.145 & 1.000 & & \\
\hline NL & 0.549 & 0.726 & 0.702 & 0.549 & 0.478 & 0.240 & 0.711 & 0.318 & 0.392 & 0.082 & 0.511 & 0.325 & 1.000 & \\
\hline PT & 0.640 & 0.676 & 0.561 & 0.336 & 0.560 & 0.327 & 0.713 & 0.429 & 0.462 & -0.012 & 0.654 & 0.166 & 0.544 & 1.000 \\
\hline SE & 0.425 & 0.669 & 0.521 & 0.476 & 0.594 & 0.734 & 0.649 & 0.444 & 0.512 & 0.048 & 0.591 & 0.074 & 0.516 & 0.330 \\
\hline
\end{tabular}

AT Austria, BE Belgium, DE Germany, DK Denmark, ES Spain, FI Finland, FR France, GB United Kingdom, GR Greece, IE Ireland, IT Italy, LU Luxembourg, NL Netherlands, PT Portugal, SE Sweden.

Significant coefficients at the $10 \%$ level are in bold. 
A quick glance at table 1 shows that most coefficients of correlation are significant at the ten percent level of confidence. On the other side all significant coefficients of correlation are positive. This means that no country has a business cycle negatively correlated with another country's. However, all significant coefficients of correlation are noticeably smaller than one for all pairs of countries. In other words, business cycles were not perfectly correlated across Europe over our period of study. ${ }^{1}$ Our study confirms the results of the literature devoted to the assessment of the convergence of business cycles across European countries. (see e.g. Cohen and Wyplosz, 1989, or Weber, 1991, and, for a survey, Frankel and Rose, 1998).

The preliminary conclusion that we can therefore draw from table 1 is that, as business cycles differ across Europe, the geographic diversification of a banking group's activities would have resulted in the diversification of its macroeconomic risk. ${ }^{2}$ The question that consequently arises is whether banking groups have taken those risk diversification possibilities into account in their decisions to develop cross-border activities. The following subsection provides a tentative answer.

\subsection{Geographic diversification of bank loans}

The second question of our analysis is to know whether European banks hold diversified loan portfolios. Our analysis concentrates on large banking groups - defined as groups whose consolidated assets are greater than 50 billion US dollars in 1997 - from EU countries. We decide to focus on large banking groups because their activities are on average more diversified between industries than those of other banks. Consequently, the use of these groups is consistent with the key assumption of our methodology according to which the return of a bank's loan portfolio in one country is measured by the growth rate of this country.

We also choose to concentrate on loans as a measure of bank operations. The reason is again our key assumption to approximate the return of a bank's loan portfolio in one country by the growth rate of that country. Indeed it makes sense to believe that the return and the risk of a portfolio of loans granted in a country are directly correlated with that country's growth rate: the better the economic situation, the lower the volume of non-performing loans.

Our analysis of the risk of loan portfolios for large European banking groups requires the aggregation of the loan portfolios of all the components of each group. We choose to adopt a control criterion to define the banks taken into account as components of a banking group. ${ }^{3}$ We assume that each bank controlled by a banking group for at least $30 \%$ is part of 
the banking group for our computation of the loan portfolios. Furthermore, we focus on banks in which banking groups' participations are as follows. When the parent company of the group is not a holding bank, we only take into account the participations directly for at least $30 \%$ of the banking group. When the parent company is a holding bank, we add another level of aggregation to include both direct participations from the holding bank and from the main banks of the group. ${ }^{4}$ We include the whole volume of loans of each bank taken into account in the loan portfolios of banking groups.

These choices are motivated by the problems that arise when consolidating banking groups. If we had not limited the level of control, the complexity of this procedure would have increased to a great extent because of never-ending indirect participations, and, on the other hand, of the crossed participations of some major banks that would result from the complex pattern of banking groups’ ownership.

Information on bank ownership and individual bank loans in 1997 is extracted from the "Bankscope" database of IBCA. Our sample includes 52 banking groups ${ }^{5}$ that are listed in annex. Breakdown of the sample of banking groups by nationality shows 14 German, 9 French, 9 British, 7 Italian, 4 Dutch, 2 Spanish, 2 Swedish, 2 Belgian, 1 Austrian, 1 Danish, and 1 Finnish. We can thus observe that the four most populated EU countries clearly dominate our sample.

A remark has here to be made about nationality: the nationality of each banking group has to be known to define whether a participation is domestic or not. In this aim, our general rule is to consider the nationality of the parent company of the group, following the criteria of IBCA: the legal location of the parent company. However, two banking groups, Dexia and Fortis, do not have such a well-specified nationality as they were established as a partnership between two banks with different nationalities. We then consider these banks as follows: when computing diversification indices, we include loans from both their home countries as domestic loans. However, when presenting loans by country, we consider the Fortis group as a Belgian group and the Dexia Group as a French group. The criterion for this choice - that only influences the presentation of the results and not the results themselves - is the country where the group has the biggest volume of loans.

We compute two indices of diversification based on bank loans data. Firstly, we measure the relative share of loans of the banking group in the home country of the group ("Home Share"). This basic indicator informs us directly on the loan activities of the group abroad. Secondly, we compute the Herfindahl indices for all banking groups. The Herfindahl index is calculated as the sum of the squared relative shares of loans in each country for every 
banking group. It takes into account the relative size and distribution of the relative shares in a portfolio and approaches zero when the loan portfolio consists of a large number of relative shares of loans by country of relatively equal size. Consequently, in comparison with the "Home Share" index, the Herfindahl index provides information about the dispersion and size of loan shares abroad.

Table 2 displays both indices of diversification alongside with the main statistics and gathers banking groups by country. ${ }^{6}$ The main result of the table is the weak diversification of loan portfolios of large European banking groups across European countries. Banking groups own on average almost 93\% of their loans in their home country. Individual diversification indices corroborate this diagnosis, as only 10 banking groups hold less than $90 \%$ of their loans in their home country. Mean Herfindahl index of $88.56 \%$ for the whole sample confirms this result, as it shows that loans abroad are not dispersed between numerous countries. ${ }^{7}$

Analysis by country suggests a higher diversification of loan portfolios for banks originating from small countries. Indeed Belgian, Dutch and Finnish banking groups have mean Herfindahl indices that are clearly lower than $80 \%$. However this is not verified in all cases, as Spanish banking groups are more diversified than Danish or Swedish ones.

The main conclusion of this subsection is that large European banking groups have not diversified their loan portfolios on a geographic basis. They hold a dominant share of their loans in their home country. Cross-border mergers were still very limited in European banking in 1997, date of our study. Cybo-Ottone and Murgia (2000) confirmed this result in their study of large listed bank merger deals that happened in Europe between 1988 and 1997. They found that more than $80 \%$ of analyzed bank-to-bank deals were domestic.

We reached two major conclusions in this section. Firstly, business cycles are not perfectly correlated between EU member countries. As a consequence, there exist opportunities for risk diversification of European banks. The answer to question Q1 is then clearly positive. However we observe that major European banking groups do not hold diversified loan portfolios across European countries. It therefore seems that they have not taken advantage of the opportunities for risk diversification that exist in Europe. We consequently provide a negative answer to question Q2. The next section aims at assessing the optimality of the choices of European banking groups. 
Table 2: Indices of diversification

\begin{tabular}{|c|c|c|c|c|c|c|}
\hline Country & $\mathbf{N}$ & Index & Mean & $\begin{array}{c}\text { Std } \\
\text { deviation }\end{array}$ & Minimum & Maximum \\
\hline \multirow[t]{2}{*}{ Austria } & 1 & "Home Share & 99.70 & . & 99.70 & 99.70 \\
\hline & & Herfindahl & 99.40 & . & 99.40 & 99.40 \\
\hline \multirow[t]{2}{*}{ Belgium } & 2 & Home Share & 94.97 & 4.75 & 91.61 & 98.33 \\
\hline & & Herfindahl & 71.14 & 18.48 & 58.07 & 84.20 \\
\hline \multirow[t]{2}{*}{ Denmark } & 1 & Home Share & 96.52 & . & 96.52 & 96.52 \\
\hline & & Herfindahl & 93.28 & . & 93.28 & 93.28 \\
\hline \multirow[t]{2}{*}{ Finland } & 1 & Home Share & 74.66 & . & 74.66 & 74.66 \\
\hline & & Herfindahl & 62.14 & . & 62.14 & 62.14 \\
\hline \multirow[t]{2}{*}{ France } & 9 & Home Share & 96.61 & 8.57 & 73.81 & 100 \\
\hline & & Herfindahl & 91.27 & 22.96 & 30.12 & 100 \\
\hline \multirow[t]{2}{*}{ Germany } & 14 & Home Share & 90.25 & 16.28 & 36.64 & 100 \\
\hline & & Herfindahl & 85.68 & 17.59 & 33.61 & 100 \\
\hline \multirow[t]{2}{*}{ Italy } & 7 & Home Share & 98.01 & 2.63 & 94.00 & 100 \\
\hline & & Herfindahl & 96.18 & 5.00 & 88.55 & 100 \\
\hline \multirow[t]{2}{*}{ Netherlands } & 4 & Home Share & 80.09 & 23.53 & 54.05 & 100 \\
\hline & & Herfindahl & 71.91 & 32.83 & 37.64 & 100 \\
\hline \multirow[t]{2}{*}{ Spain } & 2 & Home Share & 72.34 & 35.57 & 47.18 & 97.49 \\
\hline & & Herfindahl & 72.18 & 32.39 & 49.28 & 95.09 \\
\hline \multirow[t]{2}{*}{ Sweden } & 2 & Home Share & 98.33 & 1.18 & 97.50 & 99.17 \\
\hline & & Herfindahl & 96.74 & 2.27 & 95.13 & 98.34 \\
\hline \multirow[t]{2}{*}{ United Kingdom } & 9 & Home Share & 99.31 & 1.37 & 95.97 & 100 \\
\hline & & Herfindahl & 98.67 & 2.63 & 92.26 & 100 \\
\hline \multirow[t]{2}{*}{ Total } & 52 & Home Share & 92.99 & 13.85 & 36.64 & 100 \\
\hline & & Herfindahl & 88.56 & 18.69 & 30.12 & 100 \\
\hline
\end{tabular}

All figures are in percentage. N: number of observations in each country.

\section{Were European banks risk-return efficient?}

The simple observation that banking groups have not diversified their activities across countries does not allow us to conclude that they made inefficient decisions. For instance, a banking group may well have chosen to concentrate its activities in a single country whose growth rate variability is high but is compensated by a high expected growth rate, which cannot be deemed inefficient a priori. We therefore need a benchmark to assess the efficiency of banking groups' loans portfolios.

In this section, we apply the portfolio approach to judge whether the actual location of the activities of the banking groups under study provided a risk-return efficient portfolio. The first sub-section therefore describes how we adapt the portfolio methodology to study the geographic diversification of banking activities. The second sub-section displays our results. 


\subsection{Methodology}

As our paper rests on the application of the portfolio method, we must describe the assets of which the portfolios we study consist and determine the weight of each asset in those portfolios. Accordingly, and following Goldberg and Levi (2000), we suppose that European countries are the basic assets that make up a portfolio. Furthermore, each country is described by its average annual growth rate, which is the analogue to the expected return of a financial return, and the variability of its annual growth rate, which is the equivalent of the risk associated with a financial asset.

Secondly, we suppose that the weight of a country in the portfolio of a banking group is given by the share of the banking group's total loans in that country. The basic rationale for that assumption is that loans are, among all bank activities, the one that is most correlated with the level of macroeconomic activity, because of the relationship between the business cycle and the bad loan rate (see e.g. Huh and Kim, 1994). Finally, as we only focus on large banks, their activities are not restricted to a particular industry and consequently depend on the general macroeconomic context of the country where they take place.

Consequently, the share $\alpha_{i j}$ of a country $i(i=1, \ldots, 15)$ in banking group $j$ 's portfolio is given by:

$$
\alpha_{i j}=\frac{\text { loans granted by bank } j \text { in country } i}{\sum_{i=1}^{15} \text { loans granted by bank } j \text { in country } i}
$$

A similar method was adapted by Gunther and Robinson (1999) who considered portfolios of industries instead of portfolios of countries to study the risk exposure of American banking groups.

Once each country's risk and return have been defined, the overall return of a banking group's portfolio is readily obtained by weighting each country's growth rate by the relative importance of that country in the portfolio of the banking group. Accordingly, group $j$ 's return, which we denote $G_{j}$, is given by:

$$
G_{j}=\sum_{i=1}^{15} \alpha_{i j} \cdot g_{i}
$$

where $g_{i}$ is country $i$ 's average annual growth rate.

Similarly, the standard deviation of the return of a group's portfolio is obtained thanks to the following formula: 


$$
\text { stde }_{j}=\sqrt{\sum_{i=1}^{15} \sum_{k=1}^{15} \alpha_{i, j} \alpha_{k, j} \omega_{j, k}}
$$

In the above expression, $\omega_{i, k}$ denotes the covariance of country i’s growth rate with country $k$ 's. However, whenever $i=k, \omega_{i}, k$ simply denotes the variance of country $i$ 's growth rate.

With these definitions in mind, the application of the portfolio method is straightforward. The final step of our analysis is to assess the risk-return efficiency of a bank's portfolio. We therefore determine each bank's efficient portfolio, which is defined as the combination of loans that would produce the same return as the bank's actual portfolio but with a least return variability. We accordingly determine the optimal standard deviation of a group $j$ 's portfolio, which we denote $s t d o_{j} .{ }^{8}$

Finally, we measure the risk-return efficiency of a loan portfolio by computing an efficiency score which is simply given by:

$$
\text { score }_{j}=\frac{\text { stdo }_{j}}{\text { stde }_{j}}
$$

In other words, a bank $j$ 's score is the ratio of the minimum risk it could have taken had its loan portfolio been efficient to the risk it has in fact taken. A bank's score is by construction positive and smaller than one. A score equal to one denotes a perfectly efficient portfolio. On the other hand, a bank's score that is close to zero means that that bank could have reduced the variance of its portfolio to a great extent while keeping its expected return constant.

\subsection{Results}

Table 3 summarizes our results by country. The number of banking groups that were included in our sample in each country is displayed. ${ }^{9}$ Scores are averaged by country. Whenever relevant, the minimum and maximum scores are provided, as well as the standard deviation of the scores in each country.

A first glance at table 3 reveals that scores are quite low, meaning that sizeable reductions in risk could be obtained ${ }^{1}$. Their overall average amounts to $58.05 \%$. However significant discrepancies are observable. Broadly speaking, average risk-return efficiency scores range from $42.33 \%$ for the Finish bank to $62.02 \%$ for the Austrian one. In the mean

\footnotetext{
${ }^{1}$ It should be stressed that as we do no take exchange-rate risk into account, our methodology tends to underestimate overall risk, hence the benefits of diversification.
} 
time the banking groups originating from countries such as Denmark, Spain or Italy could have almost halved their risks. On the other hand, banking groups from Germany, France or the United Kingdom could have (only) cut their risks by $40 \%$.

Table 3: Risk-return efficiency scores by country

\begin{tabular}{cccccc}
\hline Country & N & Mean & Minimum & Maximum & Std Deviation \\
\hline \hline Austria & 1 & 62.02 &. &. & \\
Belgium & 2 & 58.26 & 58.04 & 58.48 & 0.32 \\
Denmark & 1 & 51.23 & $\cdot$ &. &. \\
Finland & 1 & 42.33 &. &. &. \\
France & 9 & 59.35 & 59.08 & 60.68 & 0.51 \\
Germany & 14 & 60.45 & 57.19 & 82.28 & 6.59 \\
Italy & 7 & 52.29 & 51.92 & 53.03 & 0.44 \\
Netherlands & 4 & 60.33 & 57.66 & 64.78 & 3.41 \\
Spain & 2 & 51.12 & 48.69 & 53.55 & 3.44 \\
Sweden & 2 & 55.70 & 55.41 & 55.99 & 0.41 \\
United Kingdom & 9 & 60.56 & 60.49 & 60.83 & 0.12 \\
\hline \hline Total & $\mathbf{5 2}$ & $\mathbf{5 8 . 0 5}$ & $\mathbf{4 2 . 3 3}$ & $\mathbf{8 2 . 2 8}$ & $\mathbf{5 . 3 1}$ \\
\hline AII
\end{tabular}

All figures are in percentage. N: number of observations in each country.

Owing to the weak diversification of banking groups, the main factor that explains those differences lies in the risk-return performance of their home countries. For instance, appendix A.2 reveals that Austria and Finland exhibit comparable average annual growth rates, but that growth was much more volatile in Finland over our period of study.

Moreover, the intra-country dispersion of scores visibly differs between countries. This is due to the differences in the diversification policies of banking groups of the same country. Thus, these groups may exhibit various degrees of diversification or be diversified among different countries.

Closer scrutiny of individual efficiency scores allows a more finely grained explanation of the differences in scores. ${ }^{10}$ On the extremes, German Depfa could hardly reduce its risk exposure by $17.7 \%$ whereas Finnish MeritaNordBanken may more than halve it. Those results are readily explained once one remarks that the former is already somewhat diversified, whereas the latter keeps three quarters of its loans in Finland, which has an unsatisfactory risk-return performance as was already mentioned, and has concentrated the rest of its activities in a highly correlated economy (i.e. Sweden).

Those results clearly stress that banking groups could have benefited from an efficient reduction in the risk of their environment if they had diversified their activities over our period of study. In other words, banking groups did not take advantage of the possibilities of 
risk diversification in Europe (and for some of them, no advantage at all). The answer to question Q3 is consequently clearly negative.

\section{Could have mergers improved banks' risk-return efficiency?}

The results of section 3 show that large European banking groups do not have optimal loan portfolios in terms of geographic risk diversification. The analysis concluded to the suboptimality of loan portfolios and, as a result, to the existence of potential gains in risk diversification for European banking groups.

However, it can be argued that optimal loan portfolios may imply a very dispersed presence of banking groups across Europe. These efficient portfolios may simply be unfeasible, due to the impossibility to merge a large number of banks together. Indeed, because of the costs involved by any merger deal, realistic mergers would only be operations between two banks.

Our aim in this section is to simulate hypothetical mergers between pairs of large European banking groups to observe if these mergers improve the risk-return efficiency of these groups. ${ }^{11}$ We then provide a realistic answer to the question of knowing whether European banking groups would have been able to improve their risk-return efficiency thanks to geographic diversification.

\subsection{Methodology}

The simulations of mergers are conducted on all 52 banking groups, by making pairs of groups. 1326 merged pairings were generated. The key assumption of the simulations is that the hypothetically merged banking group is simply the aggregation of the two individual banking groups. Thus, the loans of the new entity are the sum of the loans of both partners in the merger.

We measure the risk-return efficiency of hypothetically merged banking groups following the same methodology as in section 3. We compute the return and the risk of each new entity, by calculating the relative shares of loans resulting from the merger. The riskreturn efficiency score is then once again obtained, by comparing the optimal risk to the effective risk of the entity for the same level of return, according to expression 4 . We can then 
observe if any improvement in risk-return efficiency can be obtained for each partner in the merger.

The large number of banking groups in the sample precluded individual examination of all possible mergers. Instead we summarize the outcome of the study by providing results by country. It provides information about the existence of gains for banking groups from one country to merge with groups from another country. Moreover, we also examine three pairs of banking groups that merged subsequent to the estimation period. We observe if those mergers would have improved each partner's risk-return efficiency.

\subsection{Exhaustive bank pairings}

Table 4 shows results for the simulations of mergers. It gathers results by country to summarize the whole dataset of simulated mergers. Each case of the table includes two figures. The figure in bold (italic) letters indicates the mean variation (standard deviation) of efficiency scores for banking groups originating from the country mentioned at the beginning of the line when merging with banking groups originating from the country mentioned at the beginning of the column. ${ }^{12}$

Let us for instance consider the case at the intersection between the GER line and the FR column. The figure in bold letters of the case is 2.01 . This is the positive mean variation of scores for German banking groups when merging with French banking groups. For each German banking group, we computed the variation of its score when merging with each French banking group, and then we obtained the average variation of this German banking group when merging with French banking groups. The mean of the average variation of all German banking groups when merging with French banking groups was then computed.

The striking feature of table 4 is the majority of positive mean variations in the table. This means that, in most cases, European banking groups would have improved their riskreturn efficiency scores if they had merged with foreign banking groups. The scarce negative mean variations were observed for groups merging with Spanish groups or with the Finnish one. Consequently, most banking groups would be able to improve their risk-return efficiency by proceeding to cross-border mergers.

Two main factors explain the magnitude of the variations in efficiency that result from mergers. The first element is the correlation between the business cycles of the banking groups' home countries, that was presented in table 1. Due to the weak diversification of banking groups, their loan portfolios are based mostly in their home country. Consequently, 
the correlation between the home countries of both partners of the merger has an impact on the variation of efficiency scores: the higher the correlation, the lower the gains of the merger, as the banking groups involved hold loan portfolios with related movements. This fact is a well-known result of the portfolio theory: to be hedged against risk, a well-diversified portfolio must include financial assets that are not correlated.

The second element is the relative size of each partner in the merger. A banking group becomes more diversified when it merges with a foreign group of comparable size than when it merges with a partner that is an order of magnitude smaller or bigger than itself. A third factor also plays a role in the way mergers affect efficiency, though in a lesser way here: the diversification of each partner prior to the merger. However, we have shown above that only a few banking groups of our sample do hold diversified loan portfolios. Consequently, this factor does not play a major role in the interpretation of country means, but it does for a few specific mergers.

Further examination of table 4 shows strong discrepancies in mean variations of scores between countries. On one side, the nationalities of the merging partners have a deep impact on the mean variation. This finding results from the differences in the inter-country correlation of business cycles and in the average size of banking groups between countries. For instance, merging with British banking groups is very profitable for all countries’ banking groups, mainly because of the low correlation of the British economy with the other EU members.

Next to the influence of the inter-country correlation, the average size of a country's banking groups plays a major role here. Thus, the Finnish banking group is a very bad partner, especially for Danish and Swedish groups. This result stems from the fact that the Finnish group is larger than the Danish and Swedish ones. As a consequence, merging with the Finnish group leads these groups to turn to a banking group largely dominated by Finnish loans.

Furthermore, the intensity of potential gains varies a lot between countries. This is mainly the result of differences in inter-country correlations: the higher a country's correlation with other EU countries, the lower the gains for its banking groups will be. Thus, French and German banking groups reap proportionally lower gains than groups from other countries, while the Finnish banking group benefits a lot from any merger with another country, having a benefit ranging from 8.74 to 13.23 points, excluding the Nordic countries. 
Table 4: Results of simulated mergers by country

\begin{tabular}{|c|c|c|c|c|c|c|c|c|c|c|c|}
\hline Country & AT & BE & DK & FI & FR & GER & IT & NL & SE & SP & UK \\
\hline \hline AT &. & $\mathbf{2 . 6 8}$ & $\mathbf{1 . 5 2}$ & $\mathbf{- 7 . 1 5}$ & $\mathbf{2 . 2 7}$ & $\mathbf{2 . 9 6}$ & $\mathbf{1 . 3 5}$ & $\mathbf{4 . 4 4}$ & $\mathbf{6 . 3 7}$ & $\mathbf{- 2 . 0 4}$ & $\mathbf{1 2 . 0 0}$ \\
&. &. &. &. &. &. &. &. &. &. &. \\
\hline BE & $\mathbf{6 . 4 4}$ & $\mathbf{0 . 2 9}$ & $\mathbf{1 . 0 9}$ & $\mathbf{- 4 . 7 9}$ & $\mathbf{2 . 3 7}$ & $\mathbf{3 . 6 9}$ & $\mathbf{0 . 8 9}$ & $\mathbf{2 . 5 8}$ & $\mathbf{3 . 4 4}$ & $\mathbf{- 1 . 6 6}$ & $\mathbf{1 2 . 0 6}$ \\
& 0.64 & 0.32 & 0.38 & 2.01 & 0.35 & 0.52 & 0.35 & 1.12 & 0.12 & 0.66 & 0.23 \\
\hline DK & $\mathbf{1 2 . 3 0}$ & $\mathbf{8 . 1 2}$ &. & $\mathbf{- 7 . 8 0}$ & $\mathbf{8 . 8 7}$ & $\mathbf{9 . 7 2}$ & $\mathbf{2 . 9 3}$ & $\mathbf{9 . 9 6}$ & $\mathbf{6 . 4 0}$ & $\mathbf{0 . 8 0}$ & $\mathbf{1 0 . 5 0}$ \\
&. &. &. &. &. &. &. &. &. &. &. \\
\hline FI & $\mathbf{1 2 . 5 4}$ & $\mathbf{1 1 . 1 4}$ & $\mathbf{1 . 1 1}$ &. & $\mathbf{1 2 . 0 9}$ & $\mathbf{1 3 . 2 3}$ & $\mathbf{8 . 7 4}$ & $\mathbf{1 2 . 9 7}$ & $\mathbf{4 . 8 4}$ & $\mathbf{8 . 9 5}$ & $\mathbf{1 2 . 5 4}$ \\
&. &. &. &. &. &. &. &. &. &. &. \\
\hline FR & $\mathbf{4 . 9 5}$ & $\mathbf{1 . 2 8}$ & $\mathbf{0 . 7 6}$ & $\mathbf{- 4 . 9 3}$ & $\mathbf{0 . 1 2}$ & $\mathbf{3 . 1 1}$ & $\mathbf{- 0 . 1 7}$ & $\mathbf{3 . 0 2}$ & $\mathbf{2 . 7 9}$ & $\mathbf{- 2 . 9 9}$ & $\mathbf{8 . 9 5}$ \\
& 0.72 & 0.56 & 0.26 & 2.20 & 0.15 & 0.37 & 0.56 & 0.28 & 0.40 & 0.86 & 0.55 \\
\hline GER & $\mathbf{4 . 5 3}$ & $\mathbf{1 . 5 0}$ & $\mathbf{0 . 5 0}$ & $\mathbf{- 4 . 8 9}$ & $\mathbf{2 . 0 1}$ & $\mathbf{- 0 . 9 5}$ & $\mathbf{1 . 1 5}$ & $\mathbf{1 . 8 9}$ & $\mathbf{3 . 8 8}$ & $\mathbf{- 1 . 7 3}$ & $\mathbf{7 . 4 7}$ \\
& 4.07 & 5.26 & 0.34 & 9.06 & 5.16 & 4.90 & 5.30 & 4.59 & 5.42 & 6.38 & 6.05 \\
\hline IT & $\mathbf{1 1 . 0 8}$ & $\mathbf{6 . 8 6}$ & $\mathbf{1 . 8 6}$ & $\mathbf{- 1 . 2 2}$ & $\mathbf{6 . 8 8}$ & $\mathbf{9 . 3 1}$ & $\mathbf{0 . 0 2}$ & $\mathbf{8 . 9 6}$ & $\mathbf{6 . 1 6}$ & $\mathbf{1 . 2 6}$ & $\mathbf{1 3 . 7 1}$ \\
& 1.35 & 0.70 & 0.70 & 1.90 & 0.72 & 0.77 & 0.26 & 0.74 & 0.71 & 0.42 & 0.86 \\
\hline NL & $\mathbf{6 . 1 4}$ & $\mathbf{0 . 5 2}$ & $\mathbf{0 . 8 7}$ & $\mathbf{- 5 . 0 2}$ & $\mathbf{2 . 0 4}$ & $\mathbf{2 . 0 1}$ & $\mathbf{0 . 9 3}$ & $-\mathbf{0 . 6 8}$ & $\mathbf{2 . 5 9}$ & $\mathbf{- 1 . 2 8}$ & $\mathbf{8 . 1 9}$ \\
& 4.18 & 3.79 & 0.54 & 9.86 & 4.21 & 3.58 & 5.86 & 2.94 & 4.61 & 6.64 & 5.48 \\
\hline SE & $\mathbf{1 2 . 6 9}$ & $\mathbf{5 . 9 9}$ & $\mathbf{1 . 9 3}$ & $\mathbf{- 8 . 5 3}$ & $\mathbf{6 . 4 3}$ & $\mathbf{8 . 6 3}$ & $\mathbf{2 . 7 5}$ & $\mathbf{7 . 2 2}$ & $\mathbf{- 0 . 0 1}$ & $\mathbf{- 1 . 1 2}$ & $\mathbf{1 2 . 0 1}$ \\
& 0.14 & 0.30 & 0.06 & 0.40 & 0.28 & 0.29 & 0.32 & 0.28 & 0.41 & 0.42 & 0.25 \\
\hline SP & $\mathbf{8 . 8 6}$ & $\mathbf{5 . 4 8}$ & $\mathbf{0 . 9 1}$ & $\mathbf{0 . 1 6}$ & $\mathbf{5 . 2 4}$ & $\mathbf{7 . 6 0}$ & $\mathbf{2 . 4 3}$ & $\mathbf{7 . 9 3}$ & $\mathbf{3 . 4 7}$ & $\mathbf{0 . 6 6}$ & $\mathbf{1 0 . 5 6}$ \\
& 1.06 & 1.44 & 0.01 & 1.74 & 1.57 & 1.21 & 2.84 & 1.21 & 0.51 & 3.44 & 0.35 \\
\hline UK & $\mathbf{1 3 . 4 6}$ & $\mathbf{9 . 7 6}$ & $\mathbf{1 . 1 7}$ & $\mathbf{- 5 . 6 9}$ & $\mathbf{7 . 7 4}$ & $\mathbf{7 . 3 6}$ & $\mathbf{5 . 4 4}$ & $\mathbf{7 . 9 6}$ & $\mathbf{7 . 1 5}$ & $\mathbf{1 . 1 1}$ & $\mathbf{0 . 0 1}$ \\
& 1.41 & 0.68 & 0.47 & 3.04 & 0.65 & 0.34 & 0.84 & 0.32 & 0.58 & 1.89 & 0.06 \\
\hline
\end{tabular}

AT Austria, BE Belgium, DK Denmark, FI Finland, FR France, GER Germany, GR Greece, IE Ireland, IT Italy, LU Luxembourg, NL Netherlands, PT Portugal, SE Sweden, SP Spain, UK United Kingdom.

All figures are in percentage.

Additionally, the mean variations that appear on the first diagonal, representing the results of domestic mergers, are very close to zero. This is a logical consequence of the weak diversification of banking groups, which causes domestic mergers to increase the size of their portfolios without modifying the relative shares of loans in European countries. Above and beyond, it is of the highest interest to observe that domestic mergers may even result in significant losses in risk diversification. For instance, domestic mergers in Germany or Spain lead to negative changes in mean efficiency scores for more than one observation. This is an important result, as instead of concluding to the neutrality of domestic mergers in terms of risk diversification, we can then observe that the motive of geographic risk diversification leads not to undertake domestic mergers.

Finally, the low standard deviation in most cells of table 4 is also a result of the weak diversification of banking groups. As all groups from one country have very similar loan portfolios in terms of loan shares by country, the effects of mergers are similar for all banking groups from the same country. 


\subsection{A few specific bank pairings}

We now focus our analysis on three bank pairings that occurred after our period of study: the French domestic merger between BNP and Paribas, the Italian domestic merger between Banca di Roma and San Paolo IMI, the Austrian-German cross-border merger between Bank Austria and Bayerische Hypo-und Vereinsbank. Our objective here is to check if these mergers may have improved the risk diversification of the loan portfolio of each partner of the merger. In this aim, we look at the variation of the risk-return efficiency scores of each partner in the merger.

Table 5: Changes in risk diversification for recent bank mergers

\begin{tabular}{lllll}
\hline Merger & Banking group & $\begin{array}{l}\text { Pre-merger } \\
\text { score }\end{array}$ & $\begin{array}{l}\text { Post-merger } \\
\text { score }\end{array}$ & Change \\
\hline BNP-Paribas & BNP & 59.31 & 59.33 & +0.02 \\
& Paribas & 59.36 & 59.33 & -0.03 \\
\hline Banca di Roma - & Banca di Roma & 52.30 & 52.64 & +0.34 \\
San Paolo IMI & San Paolo IMI & 52.79 & 52.64 & -0.15 \\
\hline Bayerische Hypo & Bayerische Hypo & 58.79 & 62.34 & +3.55 \\
-Bank Austria & Bank Austria & 62.02 & 62.34 & +0.32 \\
\hline
\end{tabular}

All scores in percentage.

Table 5 displays the results of these mergers. Changes in scores for both domestic mergers are very weak, because of the high similarity of the country composition of loan portfolios of both merging partners. Variations are negative for Paribas and San Paolo IMI but positive for BNP and Banca di Roma. It is noteworthy that in both mergers, the more diversified bank benefits from a gain in risk diversification. The cross-border merger provides a stronger variation at least for one bank: Bayerische Hypo-und Vereinsbank faces a strong increase in its efficiency score from 58.79\% to 62.34\%, while Bank Austria only benefits from a small improvement (+0.32). Consequently, and as expected, this cross-border merger provides strong gains in risk diversification for at least one partner.

This section analyzed the risk diversification effects of mergers between all pairings of European banking groups. Our results can be summarized in two main conclusions.

Firstly, cross-border mergers provide better gains in risk diversification than domestic mergers: on one hand, table 4 shows that on average cross-border mergers generally increase risk-return efficiency scores, while domestic mergers do not have a significant impact on 
these scores. On the other hand, among the three recent mergers to which we gave a closer look, only the cross-border one provides large gains to one partner. Accordingly, the answer to question Q4 is undoubtedly positive.

Secondly, domestic mergers may have markedly reduced risk diversification. Indeed we have observed that some domestic mergers would have resulted in negative changes in efficiency scores for more than one observation. Consequently, we provide evidence against domestic bank mergers according to the geographic risk diversification motive.

\section{Conclusion}

Our aim in this paper was to analyze the motive of geographic diversification of risk in the loan activity for bank mergers in the European Union. Our conclusions clearly support the existence of potential gains in risk diversification from mergers involving partners with different nationalities. Indeed we have observed the existence of opportunities for geographic diversification in the European Union as business cycles are not perfectly correlated across EU members. Nonetheless, the largest European banking groups do not hold diversified loan portfolios, which means that their portfolios are not optimal in terms of risk diversification. We have then provided evidence about the existence of potential gains in risk diversification from cross-border mergers. In the mean time, we have also observed that domestic mergers may in fact worsen loan portfolios' risk diversification. Consequently, the major normative conclusion of this paper is that the motive of geographic risk diversification is a valid argument in favor of cross-border mergers, which was still not exploited by large European banking groups in 1997.

With so unambiguous evidence on the gains in risk diversification from cross-border bank mergers, we may wonder why these mergers did not happen, in other words why banks kept home-biased loan portfolios. A first reason is that bank managers do not fully take this argument into account. Thus, Rose (1989) observed on a sample of US mergers that when banks managers involved in mergers were asked upon their motives to merge, risk reduction was one of the least frequently mentioned answers.

A second reason is the persistence of political barriers that prevented cross-border mergers. However, as suggested by Boot (1999, p.610), “the domestic banks in Europe were and are- protected as domestic flagships”. Next to preventing cross-border mergers, this 
argument also plays a role in justifying domestic mergers in the aim of creating big national champions, less threatened by a foreign takeover.

However these barriers may disappear with the implementation of a totally integrated European banking market. With the last steps towards full integration, a wave of cross-border mergers may occur and, regardless of their motivations, result in gains in risk diversification.

\section{References}

Altunbas, Y. and P. Molyneux, 1996, Cost Economies in EU Banking Systems, Journal of Economics and Business 48, 3, 217-230.

Altunbas, Y., P. Molyneux and J. Thornton, 2000, Big-Bank Efficiency in Europe: An Analysis of the Cost Implications, Economica 64, 317-329.

Berger, A, 2000, The Big Picture of Bank Diversification, Presentation at the Conference on Bank Structure and Competition, Federal Reserve of Chicago.

Boot, A., 1999, European Lessons on Consolidation in Banking, Journal of Banking and Finance 23, 609-613.

Clark Neely, M. and D. Wheelock, 1997, Why Does Bank Performance Vary Across States ?, Review, Federal Reserve Bank of Saint-Louis, 79, Q2, 27-40.

Cohen, D. and C. Wyplosz, 1989, The European Monetary Union: An Agnostic Evaluation, in Macroeconomic Policies in an Interdependent World (Editors: D. Currie, J. Frenkel, P. Masson and R. Portes), Washington DC, Brookings, 311-37, 1989.

Copeland, T.E. and J.F. Weston, 1988, Financial Theory and Corporate Policy, Addison-Wesley Publishing Company, Reading, MA.

Craig, B. and J. Cabral Dos Santos, 1997, The Risk Effects of Bank Acquisitions, Economic Review, Federal Reserve Bank of Cleveland, Q2, 25-35.

Cybo-Ottone, A. and M. Murgia, 2000, Mergers and Shareholder Wealth in European Banking, Journal of Banking and Finance 24, 831-859.

Fatas, A., 1997, EMU: Countries or Regions? Lessons from the EMS Experience, European Economic Review 41 (1997), 743-751.

Frankel, J.A. and A.K. Rose, 1998, The Endogeneity of the Optimum Currency Area Criteria, Economic Journal 108, 1009-1025.

Goldberg, M. and M. Levi, 2000, The European Union as a Country Portfolio, European Journal of Political Economy 16, 411-427.

Gunther, J. and K. Robinson, 1999, Industry Mix and Lending Environment Variability: What Does the Average Bank Face ?, Economic and Financial Review, Federal Reserve Bank of Dallas, Q2, 24-31.

Huh, C. and S Kim., 1994, Financial Regulation and Banking Sector Performance: A Comparison of Bad Loan Problems in Japan and Korea, Economic Review, Federal Reserve Bank of San Francisco, 0, 2, 18-29.

Jacquillat, B. and B. Solnik, 1978, Multinationals are Poor Tools for Diversification, Journal of Portfolio Management 4, 2, 8-12.

Rose, P.S., 1989, Profiles of U.S. Merging Banks and the Performance Outcomes and Motivations for Recent 
Mergers, in Bank Mergers: Current Issues and Perspectives (Editor: B. E. Gup), Kluwer, 3-28.

Reichert, A.K. and L.D. Wall, 2000, The Potential for Portfolio Diversification in Financial Services, Federal Reserve Bank of Atlanta Economic Review 85 Q3, 35-51.

Shaffer, S., 1993, Can Megamergers Improve Bank Efficiency ?, Journal of Banking and Finance 17, 423-436.

Vander Vennet, R., 1996, The Effect of Mergers and Acquisitions on the Efficiency and Profitability of EC Credit Institutions, Journal of Banking and Finance 20, 1531-1558.

Weber, A., 1991, EMU and Asymmetries and Adjustment Problems in the EMS - Some Empirical Evidence, European Economy 1, 187-207.

\section{Appendix A.1: Sample of banks}

Abbey National, ABN Amro, Almanij, Banca Commerciale Italiana, Banca di Roma, Banca Intesa, Banca Nazionale del Lavoro, Banco Bilbao Vizcaya, Banco Santander Central Hispano, Bank Austria, Bankgesellschaft Berlin, Bank Nederlandse Gemeenten (BNG), Bank of Scotland, BNP, Barclays, Bayerische Hypo-und Vereinsbank, Bayerische Landesbank Girozentrale, BHW, Commerzbank, Crédit Agricole, Crédit Lyonnais, Crédit Mutuel, Credito Italiano, Depfa, Deutsche Bank, Deutsche Genossenschaftsbank, Dexia, Dresdner Bank, Foereningssparbanken, Fortis, Groupe Banques Populaires, Groupe Caisses d'Epargne, Halifax, HSBC, ING, Kreditanstalt für Wiederaufbau (KFW), Landesbank BadenWürttemberg, Landesbank Hessen, Lloyd TSB, MeritaNordBanken, Natwest, Nationwide Building Society, Norddeutsche Landesbank Girozentrale, Nykredit, Paribas, Rabobank, Royal Bank of Scotland, San Paolo IMI, Société Générale, Svenska Handelsbanken, Unicredito Italia, Westdeutsche Landesbank Girozentrale 
Appendix A.2: Descriptive statistics for growth rates

\begin{tabular}{|c|c|c|c|c|}
\hline Country & Mean & Standard dev. & Minimum & Maximum \\
\hline Austria & 0.0329 & 0.0200 & -0.0036 & 0.0713 \\
\hline Belgium & 0.0302 & 0.0222 & -0.0150 & 0.0694 \\
\hline Denmark & 0.0280 & 0.0235 & -0.0094 & 0.0927 \\
\hline Finland & 0.0321 & 0.0324 & -0.0707 & 0.0960 \\
\hline France & 0.0323 & 0.0208 & -0.0129 & 0.0699 \\
\hline Germany & 0.0288 & 0.0208 & -0.0125 & 0.0746 \\
\hline Greece & 0.0420 & 0.0359 & -0.0363 & 0.1116 \\
\hline Ireland & 0.0457 & 0.0259 & -0.0044 & 0.1115 \\
\hline Italy & 0.0339 & 0.0243 & -0.0215 & 0.0821 \\
\hline Luxembourg & 0.0382 & 0.0343 & -0.0656 & 0.1042 \\
\hline Netherlands & 0.0322 & 0.0213 & -0.0116 & 0.0827 \\
\hline Portugal & 0.0421 & 0.0326 & -0.0434 & 0.1120 \\
\hline Spain & 0.0416 & 0.0310 & -0.0113 & 0.1184 \\
\hline Sweden & 0.0250 & 0.0215 & -0.0222 & 0.0683 \\
\hline United Kingdom & 0.0233 & 0.0201 & -0.0198 & 0.0672 \\
\hline
\end{tabular}

Appendix A.3: Volumes of loans of banking groups by country

\begin{tabular}{|c|c|c|c|}
\hline Country & N & Mean & Std Deviation \\
\hline Austria & 1 & 78617381.03 &. \\
\hline Belgium & 2 & 97138129.94 & 28160136.96 \\
\hline Denmark & 1 & 5490482.42 &. \\
\hline Finland & 1 & 132485202.33 &. \\
\hline France & 9 & 123299270.43 & 50444477.80 \\
\hline Germany & 14 & 158485309.55 & 151010688.63 \\
\hline Italy & 7 & 76330061.25 & 31229473.82 \\
\hline Netherlands & 4 & 102659548.88 & 79666478.98 \\
\hline Spain & 2 & 99866702.54 & 10270860.25 \\
\hline Sweden & 2 & 64134304.81 & 3081393.96 \\
\hline United Kingdom & 9 & 115429264.53 & 51222437.70 \\
\hline
\end{tabular}

$\mathrm{N}$ : number of observations in each country. 


\section{Notes}

${ }^{1}$ We were concerned that convergence among European economies may bias our results. We consequently performed the same correlation analysis on two sub-periods (1960-1977 and 1978-1995). We observed no common trend in the evolution of the coefficients of correlation.

${ }^{2}$ For a more comprehensive study of the impact of European integration on risk diversification, the interested reader may refer to Goldberg and Levi (2000).

3 An alternative would have been to consider all loans from each bank in which the group owns any participation, and then to weight this loan volume by the ownership percentage of the group to compute the whole loan portfolio. This approach was not followed however, mainly because of the difficulties involved by the aggregation of loans with such a scenario. In particular it would be impossible to manage indirect participations beyond the third level of control.

${ }^{4}$ The motivation for this choice is the fact that holding banks do not in general hold significant volumes of loans.

${ }^{5}$ Appendix A.1 lists the banking groups included in the sample. Appendix A.3 presents the descriptive statistics for the volumes of loans by country.

${ }^{6}$ As an example, on the 'DE' line, the German banking groups have a mean Herfindahl index of $85.68 \%$ with a standard deviation of $17.59 \%$.

${ }^{7}$ Observe that if a bank with a home share of 93\%, the mean home share of our sample, has all its loans abroad in the same country, it has a Herfindahl index for $(93 \%)^{2}+(7 \%)^{2}=86.98 \%$. As the mean Herfindahl index of our sample is $88.56 \%$, we can then conclude that the dispersion of loans abroad is very weak.

${ }^{8}$ To determine an efficient portfolio, we must define the share of each country in that portfolio. We do so under the assumption that no risk-free asset is available, which is justified in our framework as no country can provide a constant growth rate, and by imposing the constraint that the volume of loans in any given country cannot be negative. For conciseness, we do not further develop the portfolio theory here. The interested reader may however refer to chapter 6 of Copeland and Weston (1988) for an exposition of the determination of efficient portfolios.

${ }^{9}$ Our sample contains no banking group whose home country is either Greece, Ireland, Luxembourg or Portugal. It must nevertheless be stressed that these countries were included as potential assets when optimal portfolios were formed. Furthermore some banking groups of our sample hold loans in these countries.

${ }^{10}$ Individual efficiency scores are available on request.

${ }^{11}$ Simulations of mergers were also performed by Shaffer (1993) on US data and Altunbas, Molyneux and Thornton (1997) on European data to study the predicted impact of mergers on bank costs. However these works have not investigated the risk diversification implied by mergers.

${ }^{12}$ Table 4 is not symmetric, as the variation of scores is computed in comparison with the banking groups whose nationality is at the beginning of the line. Consequently, the variations of scores differ for German and French banking groups when merging with one another, as their pre-merger scores are different. We of course do not include mergers of banking groups with themselves, and there is no mean variation of scores on the first diagonal for countries with only one banking group. Furthermore the standard deviation is not mentioned, whenever there is only one banking group in the analyzed country (as in Austria, Denmark, Finland). 